\title{
JULY 15, 2016 COUP OF TURKEY: COMBAT BETWEEN MODERNISM AND REVIVALISM, LESSONS TO LEARN
}

Obaid Ahmed Khan*

Atta-ur-Rahman Arif**

\begin{abstract}
If one thing that the failed coup by a small but some of the top hierarchy of Turkish armed forces on that fateful July 15, 2016 day made clear, it was: the ordinary civilians, unarmed as they were poured into the streets to defend the government whatever way they can. This massive public sympathy and support for Turkish President Erdogan and his government would be hard, if not impossible to understand, without knowing the historical intellectual, academic, and moral combat between the modernists and Islamist groups working within the country. Mustafa Kamal had turned Turkey, mostly by force, from Ottoman Empire into the secular mode using military power. Various Islamic revolutionary outfits struggled for the revival of Ottoman Empire. Among them Bedi-uzZaman Said Nursi managed to cast a strong influence. A little slow but steadfast effort influenced by Nursi movement. Islam-shy Western powers managed alternate power structure against sitting President Tayyep Erdogan. They, however, failed due to result oriented social work delivered by his regime as Mayor and Prime Minister. It is a lesson for other revolutionaries and Governments especially for Islamic revolutionaries that if politicians deliver no power can oust them like a bee from butter.
\end{abstract}

Keywords: Coup, Ottoman Empire, Ziya Gokalp, Nursi, Gollen Erdogan, modernists, revolutionists

\section{Introduction}

The coup of July 15, 2016 in Turkey has inimitably left footprint for governments, revolutionary outfits and political entities. The night of that fateful day stomached instilled nightmare in many and yet at the same time also give hopes and instilled determination in others. Apparently, ordinary Turks cast their vote of confidence to President Tayyeb Erdogan enforcing him more as their leader rather their President for he acted more like a savior than a petty politician.

Looking back at that fateful day the Turkish people appeared extremely alert to the beefed up patrolling by personnel of armed forces and quickly acted to their blockade of Bosporus and the Sultan Muhammad Fateh bridges in Istanbul, jamming of the communication system, and the menacing attempt by the rebel soldiers to force them stay inside their abodes. The international media- anti-Islam as it is- quickly sided with the rebels to start spreading rumors such as fleeing of President Erdogan to America. However, an anchor person from an international channel Al-Jazeera telecast a video message from Tayyeb Erdogan, who stood firm and talked more firmly, on a live show.

\footnotetext{
* Obaid Ahmed Khan, Ph.D. Chairman dept. of Usooluddin, Faculty Islamic Studies, University of Karach

** Atta-ur-Rahman Arif, Research Scholar, Islamic Learning Department, University of Karachi
} 
This telecast clarified that an army cluster had indeed rebelled against the government. The Turks had become used to such 'military coups' in the past in which the Army was successful to remove an elected government- installation of General Cemal Gursel in 1960, General MemduhTağmaç in 1971, and General Kan'aan Everyn in 1980.

In the past endeavors, the government leaders were either deprived of an opportunity to make direct contact with the people or were just did not enjoy the massive public support that President Erdogan enjoyed in 2016.This time around the things turned out be different because Al Jazeera's airing of Erdogan's video made the Turks flock the streets of Ankara and Istanbul to challenge the army rifles and tanks. Though some 180 Turks sacrificed their lives and another 2,000 were injured for the first time this was the first time in the history of modern Turkey an Army coup was not only foiled but the ranks and files of the rebel military officers were apprehended.

Scrutinizing the event makes it crystal clear that people defend the leaders who perform, deliver, and care are defended by the people to the hilt. No doubt that fortune did play a part because with that timely Al Jazeera telecast of Erdogan's message things might have been different.

\section{Background}

To better understand why the rebels acted as they acted it is necessary to get a peek into certain books. During the times of Ottoman Caliphate Turkey ruled a big chunk of Asia, Africa and also a thick slice of Europe. However, the primary undoing of the Empire could be attributed to luxuries, materialism, and corruption. In addition, conspiracies hatched in Europe conspiracies added with the indifference of academicians, thinkers, writers, and scholars within, made Turkey stray away from Islam. The leftover of the religious associations disappeared in the World War I when the United Forces defeated Germany and Turkey was divided by France, Italy and Britain like a prized hot cake.

\section{Modernism}

The journey of De-Islamisation or from Islam to modernism was not coincidental but it was done gradually spreading over decades. It started off with some scholars who were influenced by Europe or by French revolution. One of them was Ziya Gökalp, who was a sociologist and had interest in poetry. He managed to convince a section of Turks that Islam and the Western culture are actually two sides of the same coin and in the wave of modernism he believed in "Ijtihad". He cultivated the thought that the success of western culture lies in freedom from religion hence the Muslims should take the same alley to success. He said:

It is only by means of its civilization that Europe has been able to defeat the Muslim nations and become the Master of the world. Why then, should we hesitate in taking over this same civilization which has proved so successful? Does not our Muslim faith make it a duty for us to take over all kinds of science and learning as our Holy Prophet himself said, "Seek knowledge even if it be in China," and "Learning is the lost property of the believer; he should take it wherever he finds it?" Japan is accepted as a European power but we are 
still regarded as an Asiatic national because of our non-acceptance of European Civilization in true sense. ${ }^{1}$

Wilfred Cantwell Smith also quotes Ziya Gökalp in his book ISLAM AND MODERN HISTORY saying,

French and Germans have separate cultures, but both constitute Western civilization; so would Turks, while stressing and vitalizing their Turkish nationalism $^{2}$

In her book Islam and Modernism, American-Jewish Maryam Jameelah, who reverted to Islam also narrates from the sociologist Justice Ziya Gokalp that,

The first articulate crusader for the western concept of nationalism in the Muslim world was the Turkish Sociologist Ziya Gokalp (1876-1924) In his writings he argues that there is no incompatibility between Islam and Western civilization. He rejects the idea that Islam is a civilization and that modern Western civilization is connected with Christianity. In other words civilization and religion are two separate things. Therefore he claims that the adoption of Western civilization by Muslims will not interfere with their faith.

Now the mission of Turks is nothing but to uncover the pre-Islamic Turkish past which has remained with the people and to graft Western civilization in its entirety on to it. In order to equal the European powers militarily and in the sciences and industry, our only road to salvation is to adopt Western civilization completely.

Ziya Gokalp rejects the idea of the supremacy of the UMMAT because it conflicts with the Western concept of nationality.

Among the pre-Islamic Turks, patriotism reached its highest levels. In the future, as in the past, patriotism should be the most important area of morality for the Turks because the nation and its soil is ultimately the only self-existing unit. Loyalty to the nation must take precedence over loyalty to the family or to religion. Turkish should give highest priority to Nation and Fatherland.

Kemal Ataturk derived the inspiration for his anti-Islamic reforms directly from the philosophy of Ziya Gokalp. ${ }^{3}$

According the Ziya Gokalp if the Turks want to acquire secularism then they will have to facsimile the western socials. He also mentioned that it is a need of time that we must change our direction towards Western Civilisation. He said

When a nation advances to higher stages of its evolution, it finds it necessary to change its civilization too. When the Turks were nomadic tribesmen in Central Asia, they belonged to civilization of Far East. When they passed to the stage of the Sultanistic State they entered into the area of Byzantine civilization. And

\footnotetext{
${ }^{1}$ Maryam Jameelah, Islam and Modernism, (Lahore: Mohammad Yusuf Khan, 1966), 59-60

${ }^{2}$ Wilfred Cantwell Smith, Islam in Modern History, (New Jersey: Princeton University Press, 1957), 204

${ }^{3}$ Maryam Jameelah, Islam Versus The West, (Lahore: Sh. Muhammad Ashraf,1965), 35-37
} 
today in their transition to the nation-state they are determined to accept Western civilization. ${ }^{4}$

Ziya Gokalp used his poetry to infiltrate the thoughts in reference to the apparent differences between Science and Islam. He believed in women liberation and rights by referring it to equality. One of his poems depicts his corrupt secular thoughts below;

Surely there is an error in the interpretation of Quran by the learned

The foundation of the nation and the state is the family.

As long as the full worth of the woman is not realized national life remains incomplete;

Therefore equality is necessary in three things - in divorce, in separation and in inheritance.

As long as the woman is counted half the man as regards inheritance and in matrimony, neither the family nor the country will be elevated. ${ }^{5}$

Under the influence of these thoughts Kamal Attaturk promoted the western culture and civilization. Even though he brought forward the Islamic sentiments when he was taking charge for the independence of Turkey. But soon after politically stabilizing Turkey he carried forward on to his original goal...

The consistent efforts of Kamal Attaturk in the World War I in Tripoli made him a national leader. After defeating the Athens, Kamal Attaturk was named Ghazi and during the same time line different interactions with the ambassadors he was considered to be a champ against the West. In one of the interaction he expressed himself, saying:

To the Arab statesmen he replied in the State Assembly: "I am neither a believer in a federation of all the nations of Islam nor even in a league of all the Turkish Peoples under Soviet rule. My only aim is to safeguard the independence of Turkey within its natural frontiers - not to revive the Ottoman or any other Empire. Away with dreams and shadows! They have cost us dear in the past!" 6

According to Maryam Jameelah, originally Ziya Gokalp was a preacher of secularizing Turkey, which eventually was done by Kamal Attaturk.

She further writes:

No sooner had he assumed power than he made bold to declare that he would destroy every vestige of Islam in the life of the Turkish nation. Only when the authority of Islam was utterly eliminated could Turkey "progress" into a

${ }^{4}$ Ibid., 47

${ }^{5}$ Maryam Jameelah, Islam and modernism, (Lahore: Mohammad Yusuf Khan, 1966), 61

${ }^{6}$ Ibid., 66

${ }^{7}$ Ibid., 58 
respected, modern nation. He made speech after public speech fearlessly and brazenly attacking Islam and all Islam stands for:

"For nearly five hundred years, these rules and theories of an Arab Sheikh and the interpretations of generations of lazy and good-for-nothing priests have decided the civil and criminal law of Turkey. They have decided the form of the Constitution, the details of the lives of each Turk, his food, his hours of rising and sleeping, the shape of his clothes, the routine of the midwife who produced his children, what he learned in his schools, his customs, his thoughts - even his most intimate habits. Islam - this theology of an immoral Arab - is a dead thing. Possibly it might have suited tribes in the desert. It is no good for modern, progressive state. ${ }^{8}$

With this ideological blitz and a secular approach, Kamal Attaturk presented a bill on the March 3, 1924 which pressed for undermining Chilaphat forever and making Turkey a secular state.

Mariyam Jameelah also mentioned that:

Mustafa was now absolute dictator. The Turkish people accepted such antiIslamic "reforms" as the banning of taboush and turbans, compulsory wearing of Western clothing, Sunday as legal holiday and the Latin alphabet only at dagger's point.

About these days Huseyin Akarsu wrote in the introduction of AL-MATHNAWI ALNURI that

The founders of republic asserted that Islam and Sufism had made the Ottoman State stagnant and backward. They imposed their own style of Europeanization by abolishing the Sultanate and Caliphate, closing religious schools and religious courts, and outlawing traditional male headgear and Sufi brotherhood. They replaced Islamic legal code with a mixture of Swill civil, Italian Penal, and German commercial codes; increased women's emancipation; outlawed polygamy; made marriage and divorce civil affairs; and replaced Arabic-based Ottoman alphabet with a Latin-based one.

The annoyance from the Islamic Clerics continued even after the acceptance of the bill, which was led by a Turk Leader and an Islamic Cleric named Said Nursi. He supported Kamal Attaturk in the revolution and was also a front ally in the endeavors in the past against the Sultan but on observing the secular mindset of Kamal Attaturk he separated from him.

\section{Who is Said Nursi}

Said Nursi was a great preacher and activist of Turkey, Basically he was Kurd but whole his life struggle and preach the revival of KALIPHAT in Turkey. His work known as

\footnotetext{
${ }^{8}$ Ibid., 67

${ }^{9}$ Bediuzzman Said Nursi, translated by HuseyinAkarsu, Al-Mathnawi Al-Nuri,(Turkey: Caglayan A.S. Ismir, 2007), xiii
} 
RISALA E NOOR that was initially spread in handwritten forms and then published and now translated in various languages.

Publisher of his books Tughra Books wrote in the preface that:

The Legacy of Bedi-uz-zaman Said Nursi's (1877-1960) achievements, personality and character, and his continuing influence make him an important figure in the twentieth-century Muslim world. In a most effective and profound way Bedi-uz-zaman represents Islam's intellectual, moral, and spiritual strengths. He spend most of his life overflowing with love and ardor of Islam, employing a wise activism that is based on sound reasoning, and was developed in the shade of Qur'an and the Prophetic example. ${ }^{10}$

Said Nursi is very intelligent having robust memory has two phases in life. Although he was a great supporter of Islamic renaissance from beginning but in earlier days he also supported Mustafa Kamal during revolution.

Said Nursi's life was transformed in year 1921, when he was introduced with Sheikh Abdul Qadir Gilani through his book "FATEH UL GHAIB" and Sheikh Ahmed Sirhandi through is famous "MAKTOOBAT E RABBANI". It is mentioned in the book Islam in Modern Turkey by Shukranvahide that

First of all Abdul Qadir Gilani reached to help through his book "FATEH UL GHAIB" and by change Said Nursi saw the lines "You are in DARUL HIKMAT so for your heart remedy search for the doctor." Said Nursi said he perceived that first focus on yourself then look to others so he start searching his remedy of disease by reading that book but failed to complete the book. Afterward second incident that helped in transformation of Said Nursi is the Letters of Sheikh Ahmed Sirhandi he said "Strangely among all the letters the word BADI UZ ZAMAN appeared in only two letters and both letters appears before me at same time. So I am so happy and got the message that make your direction straight. He start searching very Philosophers and came to know that straight path is Quran only. ${ }^{11}$

Huseyin Akarsu also mentioned this change as:

Said Nursi has already changed from "Old Said" to "New Said". Withdrawing from public life, he had devoted himself to defending and explaining Islam's main principals of thought, belief, worship, morality, and way of life though writing. His words reached millions of people through 600,000 copied handwritten by him and his students. ${ }^{12}$

After that Said Nursi started to participate in the activities relevant to the implementation of Islamic Jurisprudence in Turkey. Eventually he started the Noor Movement and

\footnotetext{
${ }^{10}$ Bediuzzman Said Nursi, translated by Huseyin Akarsu, Gleams of Truth, (New Jersey: Tughra Books, 2010), xii

${ }^{11}$ Sukran Vahide, translated by Akhtar Gul, Islam in Modern Turkey, (Lahore: Jumhoori Publications, 2010), 224

${ }^{12}$ Bediuzzman Said Nursi, translated by Huseyin Akarsu, Al-Mathnawi Al-Nuri, (New Jersey: The Light Inc., 2007), xiv
} 
launched a newsletter named "Noor" to spread the message of Quran. Said Nursi himself was a Kurd but instead of working for the Nation he struggled for the Ummah (Muslims). He always considered Quran as the only option for survival and in this reference one of Sermon is significant which he delivered on his way to Syria, in front of over 10,000 people including Scholars and more than a hundred of Senior Scholars. It wasn't a routine sermon but a detailed revision of Islamic social sciences. He pointed out there the reasons of illness of Ummah in front of these scholars' gathering. Mariyam Jameelah reported that:

He delivered a stirring address in the Umayyed Mosque where he diagnosed the ills of the modern world in general and the Muslim world in particular: ${ }^{13}$

1. The prevalence of despair

2. The lack of honesty in social and political matters

3. The substitution of enmity for amity

4. Disunity among Muslims

5. The Growth of totalitarian tyranny

6. Egotism

Said Nursi also propose for the treatment of these ailments, we will have to refer to the Holy Quran because only Quran can cure such toxic syndromes.

After 1920's revolution, Said Nursi was invited in an independence celebration in Ankara. On reaching Ankara and witnessing the un-Islamic methods and customs of Kamal Atta-Turk he left, without attending the celebration. On returning, he dispatched a criticizing 10 point agenda in which he dreaded people of life after death, eternal punishment and raised their spirits for offering prayers 5 times a day and steadiness. The people, in response to his criticism, took oath upon becoming better Muslims and enjoining their religious duties. This added more to the kinks of Kamal Atta-Turk and he tried to offer Said Nursi designation, perks and accommodation. He declined the largesse of Kamal Atta Turk and flew to Wan from Ankara and decided spend the rest of his life in hibernation hibernate. Over time he started writing a Tafseer of the Holy Quran and began gathering young people to preach and spread Islam. Within no time, the message of Quran reached different counties nearby and this added more to the cares of Kamal Atta Turk. As a result, Said Nursi's companions were dealt with severely from stuffing them into the jails to death penalties and Said Nursi was casted away and was kept under strict sentry for 8 years.

Mustafa Kemal thought the best way to appease him was to appoint him as head-preacher of Anatolia province and an executive member of Dar-ul-Hikmat University. A palatial building was offered for his residence but Badee-uZaman refused everything and fled

${ }^{13}$ Maryam Jameelah, A great Islamic Movement in Turkey, (Lahore: Mohammad Yusuf Khan),1981, 9 
Ankara, living a life of, seclusion near Van. Here he gathered the young men of the neighborhood and taught them the Quran. He explained first the literal meaning and then its deeper significance and implications. Thus he placed before them the beauty of the verses, laying special stress on their spiritual, physical and mental significance in reference to the present life and the life hereafter. He vividly explained to them the secrets of nature and the various powers within the grasp of human beings which they could enjoy provided they lived a natural, honest and simple life in conformity to the Quran and the Sunnah of the Holy Prophet.

Soon the Government arrested him and his followers and sent them to jail. For eight years Badee-uz-Zaman was exiled and kept in a well-guarded jail in virtual solitary confinement where he cooked his food and washed his clothes. Inthe course of time, the jail guards also became his disciples. Here in Barla he started writing his Risala-i-Noor Quranic commentaries. Those who received them copied these tracts by hand and contributed to their wider circulation. As a result, thousands of hand-written pamphlets found their way to villages, towns, cities, schools, colleges and government offices. Of these lonely years, Badee-uz-Zaman said, "Through these sufferings of exile imprisonment and solitary confinement, I was mercifully directed to meditate only on the truth of the Quran in a state of grace."

Badee-uz-Zaman Said Nursi of Turkey was such a Mujaddid presented by Allah to the Muslim to combat the evils set loose by the notorious regime of Mustafa Kemal Ataturk. Decades have passed since the death of the dictator but the strength of Nursi's following is still growing fast. Despite all obstacles, the disciplined followers of Badee-uz-Zaman are devoting their utmost to bring about and Islamic renaissance by peaceful means working hard in literary educational and other fields of endeavor. ${ }^{14}$

One day his attention was drawn to the statement of the British minister for colonies who said "As long as the Quran is with Muslims they will be in our way. Hence we must remove it from their life." With righteous indication Badee-uz-Zaman declared to his comrade: "In the name of Allah I will devote myself to the cause of the Quran and the state of my life whatever might be the sacrilegious designs of the British Minister". With this declaration he moved to Istanbul and made arrangements to establish the Zuhra University on the model of Jamia Al-Azhar in Cairo. ${ }^{15}$

Said Nursi also faced problems when he witnessed that Sultan Abdul Hamid II was overthrown by "Committee of Union and Progress"; an organization called themselves a religious organization but influenced from Seculars and controlled by Free Masons. Mariyam Jameelah also mentioned that:

${ }^{14}$ Ibid., 5

${ }^{15}$ Ibid., 6 
Badee-uz-Zaman initiated a counter move by organizing a rival party under the name of "Ittihad-i-Mohammadi" with the same slogans of unity, freedom and reform but with this difference that its policies, program and objectives conformed to the ideology and law of Islam. He wrote essays in furtherance of the aims of his organization. Again and again he exhorted the people not to abandon the path ordained by the Holy Quran. ${ }^{16}$

He warned them that the alternative to the Quranic way of life would be the acceptance of slavery of the West.

\section{Impacts of Nursi Movement}

This movement made a great change in the lives of Turkish people and they divided in two parts, first are loyal to Islam and like to establish the Islamic rule of law, Said Nursi is symbol of this segment. Second were those who likes Western culture and keep religion away from the collective matters of life, they are called themselves Secular and Mustafa Kamal is there leader. But power is this second group is not within religion or with general public but the armed forces of the country is there power of rule. Mustafa Kamal totally changed the culture within army and all those who like Islam as a religion or as a system either fired or murdered during and after the revolution. After death of Mustafa Kamal this army became the Safeguard of Kamalist thoughts, instead of politicians and general public. On the bases of power and authority Turkish Army keep themselves active to keep Turkey on Secular pathway, further western powers of Europe and US also supports them internationally. However Nursi Movement gets relieved after Mustafa Kamal when Adnan Mandress who belongs to a religious family won the election and became the Prime Minister. He allowed AZAN in Arabic, announced to open the Masajid and seminaries for education. Said Nursi was feeling happy with these changes. But on the same time Army is not like all these acts and just after death of Said Nursi they withdrawn the Adnan Government and take over the Country.

\section{One Destination Two Pathways}

After death of Said Nursi two new movements started whose leaders have been influenced from the teaching of Said Nursi first is of Najmuddin Ebrakan who is the first person in Turkey that introduced the term "Political Islam", he chosen the path of election for change in the system. He has made political party and he also influenced with the ideology presented by Said Nursi.

Other person is Fatheullah Gollen who chose the path of service. By this path he also insisted on spiritual training of the people and character building according to the guidance of Islam. His movement first established in 1970 as a faith-inspired initiative to improve educational facilities among the country. Ideology of the Hizmat movement mentioned in the book "HIZMET" in FAQs style book. In reply of the question Is faith really a factor in the development of social movements? The author replied,

${ }^{16}$ Ibid., 7 
Yes, faith and empowerment by it form a substantial part of civic society and democracy. Faith and empowerment contribute significantly build relationships to achieve shared goals. They encourage people to compete to do good and to provide nonmaterialistic and non-contentious service. Religious experience or its influences are located at the heart of all societies. Faith is a motivating force. It helps to build relationships of trust or "social capital" for peaceful civil society movements. It does not only produce conflictual relationships. ${ }^{17}$

Both the movements worked hard towards achieving the same goal- the revival of Islam but without any confrontation. At early stage Erbakan had achieved some landmark by winning the election. But before that Government has banned his two parties with the blame of religious party, as according to constitution no religious party can be formed in Turkey. Finally he has reached in Government in 1995 and made the biggest party in the assembly but his tenure is only 2 years after that he forced to resign and RAFAH party also banned.

After the incident HIZMET also start thinking the change through politics but they used a different way and focus on education, media, defense, judiciary and channels. Millions of HIZEMT's followers present in Turkey and on the key posts of judiciary, army and universities.

On the other hand Tayyeb Erdogan was also a part of MILLI SALAMAT PARTY of ERBAKAN in the student life. He also got the lesson that how the change will be effective. He has used a long way and finally reached the post of president of Turkey. First he worked as student leader, then elected as Mayor of ISTANBUL in 1994 for a term but during a short period of four years he delivered for the people of Istanbul. In 2001 he established the Justice and Development Party (AKP) and AKP succeeded to send his Prime Minister in next election of 2002. After that Abdullah Gill became President and Tayyeb Erdogan finally become Prime Minister in 2003. During these times HIZMET also supported Erdogan when secular forces made efforts to kick them out by force. But Erdogan made his plans better. After Abdullah Gill tenure ended in 2014 Erdogan became the President of Turkey.

Initially both the movements have worked against secular forces in cooperative manner. Military establishment try hard to weak Erdogan but he strengthen the country economically and also in very slow pace restoring the Islamic values in Turkish Society. Definitely a great role of Gollen also part of the struggle made by Erdogan, as within judiciary and education fields the workers of Gollen movement were present and supportive behind the curtains because they are present in Police, Judiciary, University and Administrative positions; so supportive to Erdogan policies.

\footnotetext{
${ }^{17}$ Muhammad Cetin, Hizmet Questions and Answers on the Gullen Movement, (Turkey: Blue Dome Press,
} 2012), 2 


\section{Lessons Learned}

Through the excursion we had just look at in above pages, we must look the lessons we learned from the history.

1. Islamic revolution and renaissance is the destiny of the world and whoever tried to compel the Ummah will never be succeeded provided that the struggle will be done by with full of faith and truthful practice, as being promised by Allah SWT in Quran. ${ }^{18}$ We have witnessed that after 100 years of time Renaissance like people again came back in power by defeating the power of disciplined army and ammunition.

2. How and why two followers of same ideology part there pathway (i.e. Gollen and Erdogan), so we beheld that The major reason of differences b/w Gollen and Erdogan is time frame and approach. Hizmet argues to make the change quickly by using all the means but Erdogan's approach to use democratic for change and to be in power to implement the change because he earlier witness the end of Erbakan who start changes and thrown out by Military. Erdogan was somehow successful in his strategy with slow pace. Erdogan used this way successfully and first became Mayor of ISTANBUL in 1994, after his efforts as a Mayor when he delivered to the public; he became popular with this approach. But, on other side Gollen thinks that his time frame is so long and he is not sincere in the change but make his government stretched. Finally Gollen moved to USA in 1999, initially for medical treatment and then took immigration there. He also sent a recorded statement regarding Erdogan saying that

The existing system is still in power. Our friends who have positions in legislative and administrative bodies should learn its details and be vigilant all the time so that they can transform it and be more fruitful on behalf of Islam in order to carry out a nationwide restoration. However, they should wait until the conditions become more favorable. In other words, they should not come out too early. ${ }^{19}$

3. The events of $15^{\text {th }}$ July are evident for, that general public has a blind confidence on Erdogan that's why they laid down before the Tanks and armored to rescue the Democratic Government of Erdogan.

4. Both the parties are using different pathways to achieve their goal i.e. Revival of Islamic Caliphate but Turkey has faced a great loss after this attempt of revolution through using force of military. The self-exile of Gollen to US is also creates doubts in the minds of Islamic groups and independent observers that how it could be possible that US has allowed a person free movement, establishment of huge center within US to promote Revival of Islam. However

${ }^{18}$ Surah Al-Imran Verse No. 31

${ }^{19}$ Clement M. Henry, Rodney Wilson, The Politics of Islamic Finance, (Edinburgh University Press 2004), 236 
his approach and pathway also worked a lot and despite the help provided to Erdogan by Face-time call, the Gollen Movement has failed but they struggled in a concrete way in last 30 years.

There also a great lesson for all the revolutionary parties, political parties and Governments of Third world where post-colonialism era witnesses the quarrel between politicians and establishments (either civil or military), who safeguards the interest of western powers. If politicians move towards support, dispense basic necessities to public instead of enhance their assets and enjoying power then they get support of the public anonymously when required. It is a great study for all those who have the plan to change the life of citizens of their country and also thinks for Ummah. 